\title{
Risks associated with the use of chemicals in pond aquaculture
}

\author{
Claude E. Boyd *, Laurence Massaut \\ Department of Fisheries and Allied Aquacultures, Auburn University, Auburn, AL 36849, USA
}

Received 4 December 1998; accepted 9 February 1999

\begin{abstract}
The most common substances used in pond aquaculture are fertilizers and liming materials. Fertilizers are highly soluble and release nutrients that can cause eutrophication of natural waters. Fertilizers are also corrosive and some are highly explosive, so proper handling is necessary to prevent accidents. Some liming materials are caustic and can be hazardous to workers if proper precautions are not exercised. Liming materials do not cause environmental problems, and liming and inorganic fertilizer compounds do not present food safety concerns. An array of other substances is used less frequently in aquaculture including: oxidants, disinfectants, osmoregulators, algicides, coagulants, herbicides, and probiotics. These compounds or biological products quickly degrade or precipitate. They are not bioaccumulative and do not cause environmental perturbations in natural waters receiving pond effluents. Accidental spills of some substances could cause environmental damage. Most substances used in pond aquaculture to improve soil or water quality present little or no risk to food safety. The use of human wastes in aquaculture or the contamination of aquaculture systems with agricultural or industrial pollution could result in product contamination and food safety concerns. Some substances pose safety risks to workers, explosion or fire hazards, or cause mild pollution. (C) 1999 Elsevier Science B.V. All rights reserved.
\end{abstract}

Keywords: Chemical safety; Food safety; Environmental safety; Environmental impact

\section{Introduction}

A number of chemicals and other substances are used in pond aquaculture as

* Corresponding author. Tel.: + 1-334-844-4075; fax: + 1-334-844-5933.

E-mail address: ceboyd@acesag.auburn.edu (C.E. Boyd)

0144-8609/99/\$ - see front matter (C) 1999 Elsevier Science B.V. All rights reserved.

PII: S0144-8609(99)00010-2 
additives for improving soil and water quality and for controlling biological problems such as phytoplankton blooms, aquatic plant infestations, disease vectors, and proliferation of wild fish (Boyd, 1995a; Boyd and Tucker, 1998). Sometimes, heavy metals and pesticides enter aquaculture ponds with water used for filling, maintaining water levels, or water exchange. Aquaculturists are usually aware of human dangers encountered when handling chemicals, but they often overlook the potential impact of substances used in pond management on the surrounding environment and on the quality of aquatic food products. Because of increasing concern over the potential harm of aquaculture effluents on receiving water bodies, worries over the contamination of aquatic food products with bioaccumulative and potentially harmful chemicals, and human risks associated with storing and handling some chemicals used in aquaculture, the Food and Agriculture Organization of the United Nations (FAO, 1995) presented a Code of Conduct for Responsible Fisheries. This code asks countries to regulate the use of chemical inputs in aquaculture that are hazardous to human health and the environment, and also stresses the responsibilities of producers.

The purpose of this review is to list the major chemicals and other substances used in aquaculture ponds and comment on their food and environmental safety status and on the risks associated with handling them. The list was compiled from recent surveys on substances used in pond aquaculture for management purposes (Federal Joint Subcommittee on Aquaculture, 1994; Boyd and Tucker, 1998). The following groups of substances will be included: fertilizers, liming materials, oxidants, coagulants, osmoregulators, algicides and herbicides, piscicides, probiotics, pesticides, and heavy metals. Chemicals used exclusively for disease control or as additives in feed will not be discussed. The information presented here should be useful to those responsible for evaluating the potential human and environmental effects of pond aquaculture. In particular, this information should be helpful in the preparation of environmental impact assessments (EIAs) for aquaculture projects.

\section{Risk evaluation}

Three types of hazards, environmental, food, and handling, were considered. The level of risk associated with the use of each substance was ranked from no known risk to high potential risk with $0=$ no risk, $1=$ low risk, $2=$ medium risk, and $3=$ high risk. Risks were assigned based on an examination of the properties of the substances, product safety information provided by the manufacturers, material safety data sheets from Sigma-Aldrich-Fluka (CD-ROM, 1995), information provided in the Merck Index (Budavari, 1996), data provided by the US Environmental Protection Agency (Federal Joint Subcommittee on Aquaculture, 1994), and knowledge of the ecological effects of nutrients and other water pollutants. A risk level of 0 means that there was no evidence to establish that safety problems have ever been associated with a substance. A risk level of 1 was given to substances for 
Table 1

List of most common nitrogen fertilizer compounds with typical application rates and comments on human (HS), environmental (ES) and food (FS) safety

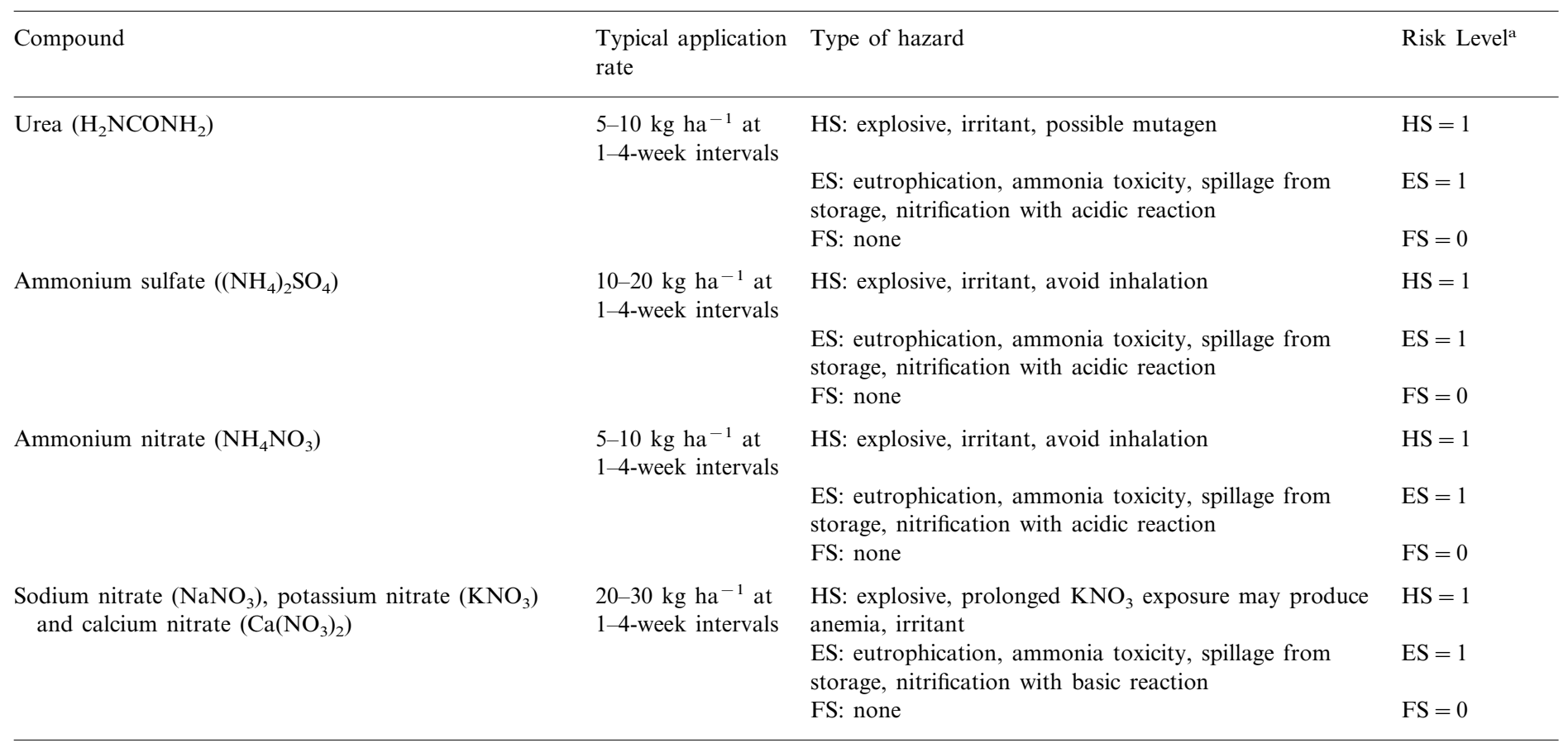

${ }^{\text {a }}$ Risk level: $0=$ no risk; $1=$ low risk; $2=$ moderate risk; $3=$ high risk. 
which there is a potential for slight safety problems based on the properties of the compound or from its use in other areas. A risk level of 2 was assigned to substances for which experience has demonstrated a moderate level of safety concerns. A rating of 3 was reserved for substances known to have caused severe safety problems in the past.

\section{Fertilizers}

Fertilizers are applied to ponds to increase plant nutrient concentrations, stimulate phytoplankton growth, and ultimately enhance production of fish or crustaceans (Boyd and Tucker, 1998). The most common inorganic fertilizers are nitrogen and phosphorus compounds, but potassium, trace metals, and silicate may be contained in some fertilizers. Fertilizers may be applied as individual compounds, or they may be blended to provide a mixed fertilizer containing two or more compounds. Organic fertilizers or manures are animal wastes or agricultural by-products which, when applied to ponds, may serve as direct sources of food for invertebrate fish food organisms and fish, or they may decompose slowly to release inorganic nutrients that stimulate phytoplankton growth. The common aquaculture fertilizer compounds, their typical application rates, and risk evaluation are provided in Tables $1-3$.

Table 2

List of most common phosphorus fertilizer compounds with typical application rates and comments on human (HS), environmental (ES) and food (FS) safety

\begin{tabular}{|c|c|c|c|}
\hline Compound & $\begin{array}{l}\text { Typical applica- } \\
\text { tion rate }\end{array}$ & Type of hazard & Risk level $^{\mathrm{a}}$ \\
\hline \multirow[t]{3}{*}{$\begin{array}{l}\text { Triple superphosphate } \\
\qquad\left(\mathrm{Ca}\left(\mathrm{H}_{2} \mathrm{PO}_{4}\right)_{2}\right)\end{array}$} & \multirow[t]{3}{*}{$\begin{array}{l}5-10 \mathrm{~kg} \mathrm{ha}^{-1} \text { at } \\
1-4 \text {-week intervals }\end{array}$} & HS: none & $\mathrm{HS}=0$ \\
\hline & & $\begin{array}{l}\text { ES: spillage from storage, eu- } \\
\text { trophication }\end{array}$ & $\mathrm{ES}=1$ \\
\hline & & FS: none & $\mathrm{FS}=0$ \\
\hline \multirow{3}{*}{$\begin{array}{l}\text { Mono- and di-ammonium } \\
\text { phosphate }\left(\mathrm{NH}_{4} \mathrm{H}_{2} \mathrm{PO}_{4}\right. \\
\left.\text { and }\left(\mathrm{NH}_{4}\right)_{2} \mathrm{HPO}_{4}\right)\end{array}$} & \multirow[t]{3}{*}{$\begin{array}{l}5-10 \mathrm{~kg} \mathrm{ha}^{-1} \text { at } \\
1-4 \text {-week intervals }\end{array}$} & $\begin{array}{l}\text { HS: irritant, monoammonium } \\
\text { phosphate is explosive }\end{array}$ & $\mathrm{HS}=1$ \\
\hline & & $\begin{array}{l}\text { ES: spillage from storage, eu- } \\
\text { trophication }\end{array}$ & $\mathrm{ES}=1$ \\
\hline & & FS: none & $\mathrm{FS}=0$ \\
\hline \multirow[t]{3}{*}{ Phosphoric acid $\left(\mathrm{H}_{3} \mathrm{PO}_{4}\right)$} & \multirow[t]{3}{*}{$\begin{array}{l}5-10 \mathrm{~kg} \mathrm{ha}^{-1} \text { at } \\
1-4 \text {-week intervals }\end{array}$} & HS: irritant & $\mathrm{HS}=1$ \\
\hline & & $\begin{array}{l}\text { ES: spillage from storage with } \\
\text { potential acidic reaction, eu- } \\
\text { trophication }\end{array}$ & $\mathrm{ES}=1$ \\
\hline & & FS: none & $\mathrm{FS}=0$ \\
\hline
\end{tabular}

\footnotetext{
${ }^{a}$ Risk levels as for Table 1.
} 
Table 3

List of other fertilizer compounds with typical application rates and comments on human (HS), environmental (ES) and food (FS) safety

\begin{tabular}{|c|c|c|c|}
\hline Compound & $\begin{array}{l}\text { Typical applica- } \\
\text { tion rate }\end{array}$ & Type of hazard & Risk level $^{\mathrm{a}}$ \\
\hline \multirow[t]{3}{*}{$\begin{array}{l}\text { Potassium chloride or muriate } \\
\text { of potash }(\mathrm{KCl})\end{array}$} & $\begin{array}{l}1-2 \mathrm{~kg} \mathrm{ha}^{-1} \text { at } \\
1-4 \text {-week inter- } \\
\text { vals }\end{array}$ & HS: irritant & $\mathrm{HS}=1$ \\
\hline & & $\begin{array}{l}\text { ES: spillage from storage } \\
\text { eutrophication }\end{array}$ & $\mathrm{ES}=1$ \\
\hline & & FS: none & $\mathrm{FS}=0$ \\
\hline \multirow[t]{3}{*}{ Sodium silicate $\left(\mathrm{Na}_{2} \mathrm{SiO}_{3}\right)$} & $\begin{array}{l}1-5 \mathrm{~kg} \mathrm{ha}^{-1} \text { at } \\
\text { 2-week intervals }\end{array}$ & HS: none & $\mathrm{HS}=0$ \\
\hline & & $\begin{array}{l}\text { ES: spillage from storage, } \\
\text { eutrophication }\end{array}$ & $\mathrm{ES}=1$ \\
\hline & & FS: none & $\mathrm{FS}=0$ \\
\hline \multirow[t]{3}{*}{$\begin{array}{l}\text { Manure, grass and human } \\
\text { wastes }\end{array}$} & $\begin{array}{l}100-500 \mathrm{~kg} \mathrm{ha}^{-1} \\
\text { dry weight } \\
\text { week }^{-1}\end{array}$ & HS: none & $\mathrm{HS}=0$ \\
\hline & & $\begin{array}{l}\text { ES: spillage from storage with } \\
\text { potential oxygen depletion, } \\
\text { eutrophication }\end{array}$ & $\mathrm{ES}=1$ \\
\hline & & $\begin{array}{l}\text { FS: disease transmission to } \\
\text { human, heavy metal } \\
\text { contamination }\end{array}$ & $\mathrm{FS}=1$ \\
\hline \multirow{3}{*}{$\begin{array}{l}\text { Trace and secondary element } \\
\text { mixes (contains various com- } \\
\text { pound of } \mathrm{Fe}, \mathrm{Zn}, \mathrm{Cu}, \mathrm{B}, \\
\text { and } \mathrm{Mo} \text { ) }\end{array}$} & $\begin{array}{l}50-100 \mathrm{~g} \mathrm{ha}^{-1} \\
\text { month }^{-1}\end{array}$ & HS: none & $\mathrm{HS}=0$ \\
\hline & & $\begin{array}{l}\text { ES: spillage from storage, } \\
\text { metal toxicity }\end{array}$ & $\mathrm{ES}=1$ \\
\hline & & FS: none & $\mathrm{FS}=0$ \\
\hline \multirow[t]{3}{*}{$\begin{array}{l}\text { Fertilizer enhancers } \\
\quad \text { (e.g., humate) }\end{array}$} & $\begin{array}{l}10-100 \mathrm{~kg} \mathrm{ha}^{-1} \\
\text { month }^{-1}\end{array}$ & HS: none & $\mathrm{HS}=0$ \\
\hline & & ES: none & $\mathrm{ES}=0$ \\
\hline & & FS: none & $\mathrm{FS}=0$ \\
\hline \multirow[t]{3}{*}{ Mixed fertilizers } & & HS: none & $\mathrm{HS}=0$ \\
\hline & & $\begin{array}{l}\text { ES: spillage from storage, } \\
\text { eutrophication }\end{array}$ & $\mathrm{ES}=1$ \\
\hline & & FS: none & $\mathrm{FS}=0$ \\
\hline
\end{tabular}

${ }^{\text {a }}$ Risk levels as for Table 1.

Primary chemical compounds used as fertilizers are highly water soluble salts of nitrogen, phosphorus, and potassium. They usually are applied in quantities necessary to increase concentrations of nitrate, ammonia, phosphate, potassium, and silicate in pond waters by $0.25-1 \mathrm{mg}^{-1}$. In addition to the primary nutrients, fertilizers usually contain a small percentage by weight of fillers and conditioners such as agricultural limestone, sand, rice hulls, granite dust, or kaolin clay (Jones, 
1979). Micronutrient elements are sometimes applied to ponds in much smaller quantities to supplement natural deficiencies. Because most micronutrients are not highly soluble, they are usually chelated. Common chelating agents are ethylenediaminetetraacetic acid, citric acid, and lignin sulfonate.

Fertilizer nutrients are absorbed by plants and enter the food web of aquaculture ponds. Seldom is more than $25 \%$ of the nutrients added to ponds in fertilizers recovered in aquatic animals at harvest (Boyd and Tucker, 1998). These nutrients occur as constituents of biomass such as protein, calcium phosphate in bones, and minerals. None of the chemical fertilizers are known to be of any hazard for food safety. The fraction of the fertilizer nutrients not harvested in aquaculture products can be found in other pond organisms, dead organic matter, and sediment, or lost in outflowing water. Nitrate can be converted to nitrogen gas by denitrification, and ammonia may be lost to the air by diffusion (Gross et al., 1999).

Because fertilizers increase nutrient concentrations in the water, they can cause nutrient enrichment when pond effluents are released into water bodies. If there are a few days between fertilizer application and water discharge to the surrounding environment, most fertilizer nutrients will have been absorbed by the pond organisms, adsorbed by sediments, or lost to the atmosphere through denitrification or ammonia volatilization. Ponds are extremely efficient in assimilating nutrients if the average hydraulic residence time is several weeks (Schwartz and Boyd, 1994). Pond bottoms are not infinite sinks for nutrients, but by periodically draining and drying pond bottoms, their capacity to assimilate nutrients can be extended. Nitrogen fertilizers have the potential to increase ammonia concentrations in the water, and excessive use can result in toxic ammonia concentrations within ponds (Boyd and Tucker, 1998). Ammonium fertilizers and urea are acidic in pond waters because nitrification releases hydrogen ions (Hunt and Boyd, 1981). Nitrate fertilizers (except ammonium nitrate) are basic because of bicarbonate produced when denitrification occurs.

Nitrogen fertilizers are explosive materials and they must be protected from contact with petroleum products, open flames, or sparks to prevent them from exploding. Nitrogen, phosphorus, and potassium fertilizers can cause skin irritation and care should be taken when handling fertilizers. Users should always read the product label for information on recommended personal protective equipment. Common-sense precautions should be followed, such as wearing gloves, longsleeved shirts and long pants, socks, shoes or boots, and protective glasses or a mask. Mixing of different products should not be attempted unless this is specifically recommended on the label. The combining of products can have many and mostly undesirable effects. For example, ammonium nitrate is often mixed with diesel fuel and used as an alternative to dynamite. Because chemical fertilizers are highly water soluble, they must be stored indoors. Large spills of fertilizers on land or in water could cause severe nutrient pollution in the surrounding areas.

Manures have much lower concentrations of nutrients than inorganic fertilizers. Because of their low nutrient content, manure application rates usually are much higher than those for chemical fertilizers (Table 3). Decomposition of manures by bacteria requires oxygen, and the amount of manure that can safely be added to a 
pond depends upon the biochemical oxygen demand of the manure. Adding manures to a pond increases the potential for low oxygen concentrations in pond water and pond effluents. Manures can sometimes be contaminated by heavy metals and present a low risk for food safety (Table 3). In some parts of the world aquaculturists use human wastes as fertilizers which increase the risk for contamination of aquatic animals with potential human pathogens. When possible, it is more desirable to use inorganic fertilizers than manures in aquaculture ponds. Manures can be more safely and efficiently disposed of as organic fertilizers and soil conditioners for terrestrial agriculture.

\section{Liming materials}

Liming materials are applied to pond waters and soils to neutralize acidity and increase total alkalinity (Boyd and Tucker, 1998). Increased alkalinity buffers water against drastic daily changes in $\mathrm{pH}$ common in eutrophic ponds with soft water. Increasing the $\mathrm{pH}$ of an acidic bottom sediment enhances the availability of phosphorus added in fertilizers (Boyd and Scarsbrook, 1974). Some calcium and magnesium from liming materials are absorbed by the pond biota to become normal constituents of plants and animals, adsorbed by the soil, or dissolved in the water. The anionic component is either neutralized by hydrogen ions or it reacts with carbon dioxide to form bicarbonate that remains in the water to increase alkalinity. It is often not necessary to lime brackish water ponds because they usually have high concentrations of total hardness and total alkalinity. However, pond sediments in coastal environments often are acidic, and the liming of pond bottoms between crops is done to neutralize acidity and stimulate microbial decomposition of the organic matter accumulated during the crop. The most common liming compounds, their typical application rates, and comments on their risk status are given in Table 4.

Burnt lime and hydrated lime are strong caustic materials, and they should be handled cautiously. Contact with the eyes can possibly cause blinding, and severe irritations can result from skin contact. If used excessively, these compounds increase water $\mathrm{pH}$ up to 10 or more and cause toxicity in aquatic plants and animals. The water $\mathrm{pH}$ will decrease to acceptable levels within a few days after applications of burnt or hydrated lime and ponds can be stocked. Agricultural limestone is safer to use, often cheaper, and considered to be the most effective liming material for ponds under normal circumstances (Boyd and Tucker, 1998). However, in ponds where severe disease problems were encountered in the previous crop, applications of burnt or hydrated lime to empty pond bottoms may be effective in destroying disease organisms in the soil before the next crop is stocked. Of course, one must wait until the lime has been deactivated by reaction with carbon dioxide and the $\mathrm{pH}$ has declined before stocking. Liming materials should be stored indoors. Large spills of burnt or hydrated lime on land or in water could cause high $\mathrm{pH}$ in the surrounding waters. None of the liming materials are known to be of any hazard for food safety. 


\section{Oxidants}

Oxidizing agents (Table 5) are used for controlling phytoplankton, killing disease organisms, or oxidizing bottom soils (Boyd, 1995b; Boyd and Tucker, 1998). Potassium permanganate has been claimed to oxidize organic and inorganic substances and kill bacteria, thereby reducing the rate of oxygen consumption by chemical and biological processes (Lay, 1971), but work by Tucker and Boyd (1977) failed to substantiate these claims. Some fish diseases are also treated by the application of potassium permanganate to fish in holding tanks or in ponds (Duncan, 1974). In water, permanganate quickly oxidizes labile organic matter and other reduced substances and is transformed to relatively non-toxic manganese dioxide which precipitates out. Potassium permanganate is toxic to phytoplankton and will reduce the production of dissolved oxygen by photosynthesis. Potassium permanganate is highly explosive when in direct contact with organic substances, and it can cause irritation to the skin. Care should be applied when handling it. There is a potential risk from spills into water because potassium permanganate can cause massive mortality of aquatic organisms.

Peroxides and chlorine compounds are powerful oxidizing agents, and they are strong irritants when highly concentrated. Calcium hypochlorite is sometimes applied to ponds to oxidize organic matter and reduce the biological oxygen demand. Recent work by Potts and Boyd (1998) revealed that chlorination of ponds with small doses of calcium hypochlorite during the production cycle does not improve water quality. However, treatment of pond water with large doses of chlorine may be an effective means of destroying disease organisms. Hypochlorite

Table 4

List of most common liming materials with typical application rates and comments on human (HS), environmental (ES) and food (FS) safety

\begin{tabular}{|c|c|c|c|}
\hline Compound & $\begin{array}{l}\text { Typical appli- } \\
\text { cation rate }\end{array}$ & Type of hazard & Risk level $^{\mathrm{a}}$ \\
\hline \multirow[t]{3}{*}{$\begin{array}{l}\text { Agricultural limestone (pulverized } \mathrm{CaCO}_{3} \text { or } \\
\qquad \mathrm{CaCO}_{3} \cdot \mathrm{MgCO}_{3} \text { ) }\end{array}$} & \multirow[t]{3}{*}{$\begin{array}{l}1-5 \text { Tons } \\
\text { ha }^{-1} \text { annually }\end{array}$} & HS: none & $\mathrm{HS}=0$ \\
\hline & & ES: none & $\mathrm{ES}=0$ \\
\hline & & FS: none & $\mathrm{FS}=0$ \\
\hline \multirow[t]{3}{*}{ Burnt lime $(\mathrm{CaO}$ or $\mathrm{CaO} \cdot \mathrm{MgO})$} & \multirow[t]{3}{*}{$\begin{array}{l}0.5-1 \text { Tons } \\
\mathrm{ha}^{-1} \text { annually }\end{array}$} & $\begin{array}{l}\text { HS: strong caustic, } \\
\text { irritant }\end{array}$ & $\mathrm{HS}=1$ \\
\hline & & $\begin{array}{l}\text { ES: spillage from } \\
\text { storage, high } \mathrm{pH}\end{array}$ & $\mathrm{ES}=1$ \\
\hline & & FS: none & $\mathrm{FS}=0$ \\
\hline \multirow{3}{*}{$\begin{array}{l}\text { Hydrated lime }\left(\mathrm{Ca}(\mathrm{OH})_{2} \text { or }\right. \\
\left.\qquad \mathrm{Ca}(\mathrm{OH})_{2} \cdot \mathrm{Mg}(\mathrm{OH})_{2}\right)\end{array}$} & \multirow{3}{*}{$\begin{array}{l}0.5-1 \text { Tons } \\
\text { ha }^{-1} \text { annually }\end{array}$} & HS: caustic, irritant & $\mathrm{HS}=1$ \\
\hline & & $\begin{array}{l}\text { ES: spillage from } \\
\text { storage, high } \mathrm{pH}\end{array}$ & $\mathrm{ES}=1$ \\
\hline & & FS: none & $\mathrm{FS}=0$ \\
\hline
\end{tabular}

\footnotetext{
${ }^{a}$ Risk levels as for Table 1.
} 
Table 5

List of most common oxidants with typical application rates and comments on human (HS), environmental (ES) and food (FS) safety

\begin{tabular}{|c|c|c|c|}
\hline Compound & Typical application rate & Type of hazard & Risk level $^{\mathrm{a}}$ \\
\hline \multirow[t]{3}{*}{ Potassium permanganate $\left(\mathrm{KMnO}_{4}\right)$} & $2-8 \mathrm{mg} \mathrm{l}^{-1}$ & $\begin{array}{l}\text { HS: explosive if in contact with organic } \\
\text { substances, irritant }\end{array}$ & $\mathrm{HS}=1$ \\
\hline & & ES: spillage from storage, toxicity & $\mathrm{ES}=1$ \\
\hline & & FS: none & $\mathrm{FS}=0$ \\
\hline \multirow[t]{2}{*}{$\begin{array}{l}\text { Hydrogen peroxide }\left(\mathrm{H}_{2} \mathrm{O}_{2}\right) \text { or calcium } \\
\text { peroxide }\left(\mathrm{CaO}_{2}\right)\end{array}$} & Up to $100 \mathrm{~kg} \mathrm{ha}^{-1}$ & $\begin{array}{l}\mathrm{HS}: \mathrm{H}_{2} \mathrm{O}_{2} \text { is irritant if highly concentrated } \\
\text { form }\end{array}$ & $\mathrm{HS}=1$ \\
\hline & & FS: none & $\mathrm{FS}=0$ \\
\hline \multirow[t]{3}{*}{ Calcium hypochlorite $\left(\mathrm{Ca}(\mathrm{OCl})_{2}\right)$} & $\begin{array}{l}30 \mathrm{mg} \mathrm{l}^{-1} \text { before stocking- } \\
0.1 \mathrm{mg}^{-1} \text { if animals present }\end{array}$ & $\begin{array}{l}\text { HS: avoid inhalation of gas, irritant, } \\
\text { poisonous }\end{array}$ & $\mathrm{HS}=1$ \\
\hline & & $\begin{array}{l}\text { ES: formation of trihalomethanes and } \\
\text { chlorinated hydrocarbons that are suspected } \\
\text { carcinogens, toxic }\end{array}$ & $\mathrm{ES}=1$ \\
\hline & & FS: none & $\mathrm{FS}=0$ \\
\hline $\begin{array}{l}\text { Sodium, potassium, or calcium nitrate } \\
\left(\mathrm{NaNO}_{3}, \mathrm{KNO}_{3} \text {, or } \mathrm{Ca}\left(\mathrm{NO}_{3}\right)_{2}\right)\end{array}$ & $5-10 \mathrm{mg} \mathrm{1}^{-1}$ & See Table 1 & See Table 1 \\
\hline
\end{tabular}

${ }^{a}$ Risk levels as for Table 1. 
Table 6

List of most common coagulants with typical application rates and comments on human (HS), environmental (ES) and food (FS) safety

\begin{tabular}{|c|c|c|c|}
\hline Compound & $\begin{array}{l}\text { Typical appli- } \\
\text { cation rate }\end{array}$ & Type of hazard & Risk level $^{\mathrm{a}}$ \\
\hline \multirow{3}{*}{$\begin{array}{l}\text { Aluminum sulfate or alum } \\
\qquad\left(\mathrm{Al}_{2}\left(\mathrm{SO}_{4}\right)_{3} \cdot 14 \mathrm{H}_{2} \mathrm{O}\right)\end{array}$} & $15-40 \mathrm{mg} \mathrm{l}^{-1}$ & HS: acidic & $\mathrm{HS}=1$ \\
\hline & & $\begin{array}{l}\text { ES: if spilled, acidity and alu- } \\
\text { minium toxicity }\end{array}$ & $\mathrm{ES}=1$ \\
\hline & & FS: none & $\mathrm{FS}=0$ \\
\hline \multirow[t]{3}{*}{ Ferric chloride $\left(\mathrm{FeCl}_{3}\right)$} & $15-40 \mathrm{mg}^{-1}$ & HS: irritant & $\mathrm{HS}=1$ \\
\hline & & ES: if spilled, acidity and toxicity & $\mathrm{ES}=1$ \\
\hline & & FS: none & $\mathrm{FS}=0$ \\
\hline \multirow{3}{*}{$\begin{array}{l}\text { Calcium sulfate or gypsum } \\
\qquad\left(\mathrm{CaSO}_{4} \cdot 2 \mathrm{H}_{2} \mathrm{O}\right)\end{array}$} & $250-500 \mathrm{mg} \mathrm{l}^{-1}$ & HS: none & $\mathrm{HS}=0$ \\
\hline & & ES: none & $\mathrm{ES}=0$ \\
\hline & & FS: none & $\mathrm{FS}=0$ \\
\hline
\end{tabular}

${ }^{\text {a }}$ Risk levels as for Table 1.

can form trihalomethanes (THMs) and chlorinated hydrocarbons during oxidation of organic matter. These compounds are suspected carcinogens (White (1992), pp. 359-364). Sodium, potassium, and calcium nitrate are sometimes used as oxidizing agents (Boyd and Tucker, 1998). Nitrate compounds have a basic reaction when they are used by bacteria to support anaerobic decomposition (denitrification).

Oxidants are transformed to inactive forms when they react with organic matter. There is no evidence that any of these compounds other than chlorine compounds leave harmful residues in the water or accumulate in the tissues of aquatic organisms, so no food hazard is associated with them. Although chlorine compounds have been reported to form residual compounds that are suspected carcinogens, they have a long history of safe and beneficial use in the disinfection of drinking water (White, 1992). Therefore, we feel that the use of chlorine compounds in aquaculture does not pose a significant food safety risk, but there is some possibility of environmental contamination by reaction products of chlorine in effluents.

\section{Coagulants}

Coagulants (Table 6) are applied to pond waters to flocculate suspended clay particles and cause them to precipitate in order to clear the water of turbidity (Boyd, 1979; Boyd and Tucker, 1998). Calcium sulfate (gypsum) dissolves in water to increase calcium and sulfate concentrations. Calcium and sulfate may be absorbed in small amounts by plants and animals to become normal biological constituents. Aluminum and ferric iron ions from aluminum sulfate and ferric 
chloride applications quickly precipitate as aluminum and iron oxides. Nevertheless, these two compounds have a strongly acidic reaction in water because of the hydrolysis of iron and aluminum. Because of their high potential to create acidity, they should be stored indoors and risks of spills minimized. Aluminum sulfate and ferric chloride both should be handled with care because skin irritation can result from contact. None of these coagulants are bioaccumulative and should not be of any hazard to food safety.

\section{Osmoregulators}

These substances are applied to water to increase the salinity or the calcium concentration and improve conditions for osmoregulation by certain culture species (Boyd and Tucker, 1998). They are simple salts that dissolve in the water and have little influence on the composition of aquatic animal products. The two most common osmoregulators are sodium chloride and calcium sulfate (Table 7).

\section{Algicides and herbicides}

Algicides and herbicides are applied to ponds to reduce the abundance of nuisance aquatic plants. Excessive phytoplankton may result in chronically low dissolved oxygen concentrations during the night, and blue-green algae are responsible for off-flavor in fish and crustaceans (Tucker and Robinson, 1990). Larger aquatic plants create dense communities that interfere with feeding and harvest. A number of herbicides are used to control weeds in aquatic ecosystems, but only a few of them have been cleared in the USA for use in aquaculture ponds (Federal Joint Subcommittee on Aquaculture, 1994). Because of their expense and lack of effectiveness relative to mechanical and biological control techniques, their use is seldom justified in aquaculture. A variety of algicides has been used in ponds, but four, copper sulfate, chelated copper compounds, simazine, and potassium ricinoleate, have been employed most extensively in the USA (Table 8). These

Table 7

List of most common osmoregulators with typical application rates and comments on human (HS), environmental (ES) and food (FS) safety

\begin{tabular}{llll}
\hline Compound & $\begin{array}{l}\text { Typical application } \\
\text { rate }\end{array}$ & Type of hazard & Risk level $^{\mathrm{a}}$ \\
\hline Salt $(\mathrm{NaCl})$ & $100-2000 \mathrm{mg} \mathrm{1^{-1 }}$ & HS: irritant & ES: increase in salinity $=1$ \\
& & $\begin{array}{l}\text { FS: not generally considered } \\
\text { poisonous } \\
\text { See Table } 6\end{array}$ & $\mathrm{FS}=0$ \\
$\begin{array}{l}\text { Calcium sulfate or } \\
\text { gypsum }\left(\mathrm{CaSO}_{4} \cdot 2 \mathrm{H}_{2} \mathrm{O}\right)\end{array}$ & $100-400 \mathrm{mg} \mathrm{l}^{-1}$ & & See Table 6
\end{tabular}

\footnotetext{
${ }^{a}$ Risk levels as for Table 1.
} 
Table 8

List of most common algicides and herbicides with typical application rates and comments on human (HS), environmental (ES) and food (FS) safety

\begin{tabular}{|c|c|c|c|}
\hline Compound & $\begin{array}{l}\text { Typical application } \\
\text { rate }\end{array}$ & Type of hazard & Risk level $^{\mathrm{a}}$ \\
\hline $\begin{array}{l}\text { Copper sulfate } \\
\qquad\left(\mathrm{CuSO}_{4} \cdot 2 \mathrm{H}_{2} \mathrm{O}\right)\end{array}$ & $0.5-2 \mathrm{mg}^{-1}$ & $\begin{array}{l}\text { HS: strong irritant } \\
\text { ES: toxic to aquatic life in high } \\
\text { concentrations } \\
\text { FS: not bioaccumulative }\end{array}$ & $\begin{array}{l}\mathrm{HS}=1 \\
\mathrm{ES}=2 \\
\mathrm{FS}=0\end{array}$ \\
\hline $\begin{array}{l}\text { Chelated copper } \\
\text { compounds }\end{array}$ & $0.2-1 \mathrm{mg} \mathrm{l}^{-1}$ & $\begin{array}{l}\text { HS: none } \\
\text { ES: copper can be toxic to } \\
\text { aquatic life if high doses utilized } \\
\text { FS: none }\end{array}$ & $\begin{array}{l}\mathrm{HS}=0 \\
\mathrm{ES}=2 \\
\mathrm{FS}=0\end{array}$ \\
\hline $\begin{array}{l}\text { Simazine }\left(\mathrm{C}_{7} \mathrm{H}_{12} \mathrm{ClN}_{5}\right. \\
\text { 1,3,5-triazine herbicide })\end{array}$ & $0.25-1.0 \mathrm{mg}^{-1}$ & $\begin{array}{l}\text { HS: none } \\
\text { ES: none } \\
\text { FS: none }\end{array}$ & $\begin{array}{l}\mathrm{HS}=0 \\
\mathrm{ES}=0 \\
\mathrm{FS}=0\end{array}$ \\
\hline $\begin{array}{l}\text { Dyes (food coloring } \\
\text { compounds) }\end{array}$ & $1-5 \mathrm{mg} \mathrm{l}^{-1}$ & $\begin{array}{l}\text { HS: none } \\
\text { ES: none } \\
\text { FS: none }\end{array}$ & $\begin{array}{l}\mathrm{HS}=0 \\
\mathrm{ES}=0 \\
\mathrm{FS}=0\end{array}$ \\
\hline $\begin{array}{l}\text { Potassium ricinoleate } \\
\qquad\left(\mathrm{KC}_{18} \mathrm{H}_{34} \mathrm{O}_{3}\right)\end{array}$ & $0.25-1.0 \mathrm{mg} \mathrm{l}^{-1}$ & $\begin{array}{l}\text { HS: none } \\
\text { ES: none } \\
\text { FS: none }\end{array}$ & $\begin{array}{l}\mathrm{HS}=0 \\
\mathrm{ES}=0 \\
\mathrm{FS}=0\end{array}$ \\
\hline
\end{tabular}

${ }^{\text {a }}$ Risk levels as for Table 1.

compounds are accepted by the US Environmental Protection Agency for application and use in aquatic sites (Federal Joint Subcommittee on Aquaculture, 1994).

Copper inhibits both respiration and photosynthesis in algae (Boyd and Tucker, 1998). High doses of copper sulfate may be acutely toxic to fish, but copper compounds quickly precipitate from water as copper oxide and toxicity can be avoided if the dose does not exceed one hundredth of the total alkalinity concentration of the water to be treated. Some copper may be absorbed by organisms, but concentrations in tissues are no greater than those normally found in native plants and fish. Decapod crustaceans also have the ability to regulate essential trace elements, such as copper and zinc, at least to some degree (White and Rainbow, 1982). No food hazard is associated with copper sulfate use. Copper is often chelated with citric acid or triethanol amine to increase its solubility and residual time in water. These organic ligands are degraded fairly quickly by bacteria in ponds, and they do not accumulate in plants and animals (Masuda and Boyd, 1993).

Simazine is a powerful photosynthesis inhibitor and is extremely toxic to phytoplankton but non-toxic to fish at the treatment rates used for algal control. Simazine is degraded by bacteria, its half-life is about 2 weeks (Tucker and Boyd, 1978), and it is not known to be bioaccumulative. Potassium ricinoleate is a 
saponified fatty acid (Scott et al., 1989). It is degraded by bacteria and is not bioaccumulative. Sometimes dyes are used in aquaculture to shade the pond bottom and limit light for underwater weeds. These are food dyes that have a half-life of a month or more. They are not bioaccumulative or directly toxic to plants and animals (Boyd and Noor, 1982).

In summary, copper sulfate, chelated copper compounds and simazine are very effective algicides. They may cause problems in ponds with low dissolved oxygen concentrations immediately after treatment, but they have not been reported to cause ecological problems in receiving waters. None of these algicides are known to be bioaccumulative and should not be of any hazard to food safety. They should be stored properly and risks of spills kept to a minimum.

\section{Piscicides}

The most common piscicides are teaseed cake, rotenone, lime, potassium permanganate, and ammonium fertilizer (Table 9). The concentrations of these compounds used for eradicating fish vary widely. The entire pond volume is sometimes treated, but usually treatment is limited to puddles of water that remain in the bottom of ponds after harvest. The compounds are degraded by natural processes before the fish and shrimp are stocked for the next crop. No food safety hazards are thought to be associated with piscicides.

Table 9

List of most common piscicides with typical application rates and comments on human (HS), environmental (ES) and food (FS) safety

\begin{tabular}{|c|c|c|c|}
\hline Compound & $\begin{array}{l}\text { Typical application } \\
\text { rate }\end{array}$ & Type of hazard & Risk level $^{\mathrm{a}}$ \\
\hline \multirow{3}{*}{$\begin{array}{l}\text { Teaseed cake (active } \\
\text { ingredient is sapogenin } \\
\text { glycosides) }\end{array}$} & \multirow[t]{3}{*}{$15 \mathrm{mg} \mathrm{l}^{-1}$} & $\begin{array}{l}\text { HS: powerful hemolytic when } \\
\text { injected into the blood system }\end{array}$ & $\mathrm{HS}=0$ \\
\hline & & $\begin{array}{l}\text { ES: foam strongly, form oil- } \\
\text { in-water emulsions and act as } \\
\text { protective colloids }\end{array}$ & $\mathrm{ES}=1$ \\
\hline & & FS: none & $\mathrm{FS}=0$ \\
\hline \multirow[t]{3}{*}{ Rotenone $\left(\mathrm{C}_{23} \mathrm{H}_{22} \mathrm{O}_{6}\right)$} & \multirow{3}{*}{$0.25-2.0 \mathrm{mg}^{-1}$} & HS: avoid inhalation-irritant & $\mathrm{HS}=1$ \\
\hline & & ES: low residual time, toxicity & $\mathrm{ES}=1$ \\
\hline & & FS: none & $\mathrm{FS}=0$ \\
\hline Lime & & See Table 4 & See Table 4 \\
\hline $\begin{array}{l}\text { Potassium permanganate } \\
\qquad\left(\mathrm{KMnO}_{4}\right)\end{array}$ & & See Table 5 & See Table 5 \\
\hline Ammonium fertilizer & $0.01 \mathrm{~kg}$ of urea $\mathrm{m}^{-3}$ & See Table 1 & See Table 1 \\
\hline \multirow{3}{*}{$\begin{array}{l}\text { Formalin-formaldehyde } \\
\text { solution }\end{array}$} & & HS: avoid inhalation, irritant & $\mathrm{HS}=2$ \\
\hline & & ES: toxicity & $\mathrm{ES}=1$ \\
\hline & & FS: none & $\mathrm{FS}=0$ \\
\hline
\end{tabular}

\footnotetext{
${ }^{a}$ Risk levels as for Table 1.
} 
Table 10

List of most common probiotics with typical application rates and comments on human (HS), environmental (ES) and food (FS) safety

\begin{tabular}{llll}
\hline Compound & Typical application rate & Type of hazard & Risk level $^{\mathrm{a}}$ \\
\hline $\begin{array}{l}\text { Live bacterial inocula (non- } \\
\text { pathogenic organisms and } \\
\text { usually Bacillus species) }\end{array}$ & $\begin{array}{l}1-2 \mathrm{mg} \mathrm{l}^{-1} \text { at } 1 \text { or } 2 \text { days to } \\
1 \text {-week intervals }\end{array}$ & HS: none & HS $=0$ \\
& & ES: none & ES $=0$ \\
& & FS: none & FS $=0$ \\
$\begin{array}{lll}\text { Fermentation products rich in } \\
\text { extracellular enzymes }\end{array}$ & $1-2 \mathrm{mg} \mathrm{l}^{-1}$ at 1 or 2 days to & HS: none & HS $=0$ \\
& & ES: none & ES $=0$ \\
& & FS: none & FS $=0$
\end{tabular}

${ }^{\text {a }}$ Risk levels as for Table 1.

\section{Probiotics}

The common probiotics used in pond management are live bacterial inocula (non-pathogenic organisms and usually Bacillus species) and fermentation products rich in extracellular enzymes. Claims about the potential benefits of probiotics in aquaculture ponds include: enhanced decomposition of organic matter; reduction in nitrogen and phosphorus concentrations; better algal growth; greater availability of dissolved oxygen; reduction in blue-green algae; control of ammonia, nitrite, and hydrogen sulfide; lower incidence of disease and greater survival; and better shrimp and fish production. However, studies have shown very few positive benefits resulting from the addition of probiotics (Boyd and Gross, 1998; Queiroz and Boyd, 1998; Queiroz et al., 1998). The mechanisms of probiotice action are not known and the conditions under which improvements may be expected have not been identified. These products normally are applied at $1-2 \mathrm{mg}^{-1}$ at intervals of 1 or 2 days to 1 week or more (Table 10). The addition of probiotics to aquaculture ponds should not results in any damage to the fish or shrimp crop or to the environment. No food safety hazards are thought to be presented by probiotics.

\section{Miscellaneous}

Zeolite is an aluminosilicate clay of high cation exchange capacity (Mumpton, 1984). It is applied to shrimp ponds in Asia at $20-50 \mathrm{~kg} \mathrm{ha}^{-1}$ and often at weekly intervals (Table 11) because shrimp farmers mistakenly think that it will reduce ammonia concentrations (Boyd, 1995a). It settles to the pond bottom and does not enter the food chain. Zeolite does not cause food safety problems or environmental threats.

Extracts from plants of the genus Yucca contain glycocomponents that can adsorb ammonia (Wacharonke, 1994). Application rates of $1-2 \mathrm{mg}^{-1}$ per month 
have been suggested for ammonia removal from pond waters (Table 11). Yucca extracts are degraded by bacteria and no food safety hazards or environmental threats result from their use.

Bactericides such as $\mathrm{BKC}$, providone iodine, glutaraldehyde, and formalin are added to pond water at concentrations of $1-10 \mathrm{mg}^{-1}$ in attempts to prevent excessive development of pathogenic bacteria (Table 11). These compounds are probably degraded by bacteria, but little information is known about the possibility that these compounds, their reaction products, or their degradation products are bioaccumulative. There is no reason for bactericides to be applied to the water in aquaculture ponds, and their use should be discouraged because of questions related to food safety (Boyd and Tucker, 1998).

Sodium bicarbonate may be applied to pond waters for reasons that are not clear to the authors. Concentrations may be $25 \mathrm{mg}^{-1}$ or higher, but no food safety or environmental hazards result from sodium bicarbonate addition (Table 11).

Table 11

List of miscellaneous treatments with typical application rates and comments on human (HS), environmental (ES) and food (FS) safety

\begin{tabular}{|c|c|c|c|}
\hline Compound & $\begin{array}{l}\text { Typical applica- } \\
\text { tion rate }\end{array}$ & Type of hazard & Risk level $^{\mathrm{a}}$ \\
\hline \multirow[t]{3}{*}{ Zeolite (aluminosilicate clay) } & $\begin{array}{l}20-50 \mathrm{~kg} \mathrm{ha}-1 \\
\text { at weekly inter- } \\
\text { vals }\end{array}$ & HS: = none & $\mathrm{HS}=0$ \\
\hline & & ES: none & $\mathrm{ES}=0$ \\
\hline & & FS: none & $\mathrm{FS}=0$ \\
\hline \multirow[t]{3}{*}{ Yucca extracts } & $\begin{array}{l}1-2 \mathrm{mg}^{-1} \\
\text { month }^{-1}\end{array}$ & HS: none & $\mathrm{HS}=0$ \\
\hline & & ES: none & $\mathrm{ES}=0$ \\
\hline & & FS: none & $\mathrm{FS}=0$ \\
\hline \multirow{3}{*}{$\begin{array}{l}\text { Bactericides: BKC (alkyldimethyl-benzylammo- } \\
\text { nium chloride), providone iodine (polyvinyl- } \\
\text { pyrrolidone iodine), glutaraldehyde, formalin }\end{array}$} & $1-10 \mathrm{mg}^{-1}$ & HS: none & $\mathrm{HS}=0$ \\
\hline & & $\begin{array}{l}\text { ES: low residual } \\
\text { time but toxic }\end{array}$ & \\
\hline & & $\begin{array}{l}\text { FS: possible } \\
\text { toxicity }\end{array}$ & $\mathrm{FS}=1$ \\
\hline \multirow[t]{3}{*}{ Sodium bicarbonate $\left(\mathrm{NaHCO}_{3}\right)$} & $\begin{array}{l}25 \mathrm{mg} \mathrm{l}^{-1} \text { or } \\
\text { higher }\end{array}$ & HS: none & $\mathrm{HS}=0$ \\
\hline & & ES: none & $\mathrm{ES}=0$ \\
\hline & & FS: none & $\mathrm{FS}=0$ \\
\hline \multirow[t]{3}{*}{ Iron oxide $(\mathrm{FeO})$} & $1 \mathrm{~kg} \mathrm{~m}^{-2}$ & HS: none & $\mathrm{HS}=0$ \\
\hline & & ES: none & $\mathrm{ES}=0$ \\
\hline & & FS: none & $\mathrm{FS}=0$ \\
\hline \multirow[t]{3}{*}{ KILOL (extracts of grapefruit seed) } & & HS: none & $\mathrm{HS}=0$ \\
\hline & & ES: none & $\mathrm{ES}=0$ \\
\hline & & FS: none & $\mathrm{FS}=0$ \\
\hline
\end{tabular}

\footnotetext{
${ }^{\text {a }}$ Risk levels as for Table 1.
} 
Iron oxide has been applied to ponds to precipitate hydrogen sulfide (Chamberlain, 1988). The application rate is about $1 \mathrm{~kg} \mathrm{~m}^{-2}$ of pond bottom (Table 11). The iron oxide and iron sulfide precipitate and have little influence on the pond biota. Food safety hazards and negative environmental impacts would not result from use of iron oxide.

A product called KILOL is made from extracts of grapefruit seed and results in a mixture of ascorbic acid and large amounts of amino trace elements. It is applied to shrimp ponds in Ecuador as a general water quality enhancer, either directly or mixed with lime (Table 11). It is also sometimes mixed into shrimp feed to control disease (Boyd and Gross, 1998). Both major components of KILOL are listed on the GRAS list by the US Food and Drug Administration and so are considered as generally safe if added directly to human food. In addition, KILOL does not cause environmental harm.

Sodium chloride is commonly applied to channel catfish ponds to increase chloride concentrations to 20 times nitrite concentrations (Tucker et al., 1989). A chloride:nitrite ratio of 20:1 prevents channel catfish from absorbing enough nitrite to cause methemoglobinemia (brown blood disease). Application rates seldom exceed $50 \mathrm{mg}^{-1}$ chloride. Increases in chloride concentration are not large enough to result in salinization of surface or underground waters. Salt does not represent a food or human safety hazard.

\section{Insecticides and heavy metals}

Insecticides have sometimes been applied to ponds to kill unwanted organisms before stocking with fish or shrimp. Many of these compounds are bioaccumulative and could contaminate the final product. However, the use of some insecticides can be justified in restricted cases. In South and Central America, some shrimp farms have been plagued by the ghost shrimp (Lepidophthalmus spp.) which borrows into bottom soils in large numbers and competes with the shrimp crop for food. The only effective control that has been discovered is the application of a carbamate pesticide (Sevin) to the bottom of empty ponds. This compound is known to decompose quickly and its by-products are not harmful to the environment, so its use for the control of ghost shrimp seems acceptable from environmental and food safety standpoints. In most other instances, use of insecticides in aquaculture ponds should be discouraged (Table 12).

Insecticides, other pesticides, and heavy metals can enter aquaculture ponds in pollution. The substances can be toxic to the culture species, and they can contaminate the harvested product (Avault, 1996). The list of pesticides that could occur in aquaculture products is too long to present here. The heavy metals that present the greatest threat to contamination of aquaculture products are lead, mercury, arsenic, beryllium, cadmium, chromium, manganese, silver, and zinc (Table 12). Aquaculturists are well aware of the potential threat of pollution to the survival of their crops, so it is rare that ponds are built in areas where a high degree 
Table 12

List of potential pesticides and heavy metals that could enter aquaculture ponds through contamination, with comments on human (HS), environmental (ES) and food (FS) safety

\begin{tabular}{lll}
\hline Compound & Type of hazard & Risk level $^{\mathrm{a}}$ \\
\hline Insecticides & HS: toxic & $\mathrm{HS}=2$ \\
& ES: bioaccumulative & $\mathrm{ES}=3$ \\
& FS: bioaccumulative & $\mathrm{FS}=3$ \\
& HS: toxic & $\mathrm{HS}=2$ \\
& ES: bioaccumulative & $\mathrm{ES}=3$ \\
& FS: bioaccumulative & $\mathrm{FS}=3$ \\
& HS: most are toxic to human if & $\mathrm{HS}=3$ \\
$\begin{array}{l}\text { Heavy metals: lead, mercury, arsenic, } \\
\text { beryllium, cadmium, chromium, } \\
\text { manganese, silver, and zinc }\end{array}$ & absorbed, some carcinogenic & \\
& ES: bioaccumulative & $\mathrm{ES}=3$ \\
& FS: bioaccumulative & $\mathrm{FS}=3$ \\
Aluminum, antimony, barium, copper, & HS: less toxic than above, but high \\
cyanide, iron, nickel, and selenium & concentrations when absorbed will be & $\mathrm{HS}=2$ \\
& toxic & \\
& ES: not bioaccumulative & $\mathrm{ES}=2$ \\
& FS: not bioaccumulative & $\mathrm{FS}=3$ \\
\hline
\end{tabular}

${ }^{\text {a }}$ Risk levels as for Table 1.

of external contamination is likely. Thus, accidental contamination of aquaculture products with pesticides or heavy metals from pollution is probably a rare event.

\section{Fuels and lubricants}

As for any other farm operations, aquaculture production requires the use of fuel and lubricants for vehicles and power units used on the farm. Unless the materials are stored, used, and disposed in a proper way, they present both an environmental and safety hazard. Spills of fuels and lubricants can contaminate surrounding water and soil, or through runoff find their way into pond waters. Fish and other aquatic animals exposed to petroleum products may develop characteristic off-flavors variously described as 'oily', 'diesel fuel', 'petroleum', or 'kerosene', and be rejected from the market (Boyd and Tucker, 1998). Fires and explosions can result from careless handling of petroleum compounds or improper storage.

Fuels should be stored above ground in high-quality storage tanks. These tanks should have vents with 3-4 m high vent pipes to remove vapor. The tanks should be clearly marked as flammable and the nature of their contents identified. The tanks should be placed inside impervious containment basins of 1.5 times tank volume. These basins would capture spilled fuel during tank filling or following the rupture of a tank. Rain water must be pumped from the containment basin at regular intervals to prevent loss of containment volume. Lubricants should be 
stored in buildings with concrete floors and drains that empty into a containment area for capturing any spilled fluids. The building and areas where vehicles and other machines are repaired, serviced, or refueled also should have concrete floors with drains into containment areas. All sites where fuels and lubricants are used should be designated as containing flammable material. All used oils should be collected in suitable containers and shipped to a recycling center. Spilled fuel should be pumped from containment areas and stored in tanks until it can be properly disposed of.

\section{Summary}

Most chemicals used in aquaculture management pose little or no food safety risk. However, some farmers may apply insecticides and bactericides to ponds, and these substances can be bioaccumulative and present a food safety hazard. Accidental contamination of aquaculture products by pesticides and heavy metals does not appear to be a major risk. Although aquaculture chemicals are generally not a food hazard, some of the compounds pose risks to workers who apply them to ponds, some are flammable or explosive, and some can cause environmental pollution. Enrichment of water in aquaculture ponds is desirable, but the direct discharge of such waters may not always be environmentally sound. Management practices that will reduce potential problems from aquaculture effluents should be promoted and implemented on a larger scale. Several aquaculture associations have developed codes of management practices for use by their members to encourage better management and environmental stewardship. A comprehensive set of general codes of practice was developed by the Global Aquaculture Alliance for use in developing detailed, site-specific practices (Boyd, 1999).

In most nations, aquaculture is considered as a new industry and adequate guidelines and regulations regarding use of chemicals and other substances have not been formulated. The adoption of best management practices (BMPs) by aquaculturists is a practical way to approach environmental management of aquaculture until the formulation and enforcement of reasonable regulations. BMPs are practices thought to be the most effective, yet practical, methods of reducing environmental impact levels to those compatible with resource management goal (Hairston et al., 1995). A list of BMPs pertaining to the use of chemicals and other substances in aquaculture ponds follows: (1) Where countries have approved lists of chemicals and chemical uses, only approved chemicals should be used in ponds and only for the use approved. Where such lists are not available, the aquaculture industry and individual producers should work with governments to prepare such lists. (2) Aquaculturists should follow information on product labels regarding dosage, withdrawal period, proper use, storage, disposal, and other constraints on the use of a chemical including environmental and human safety precautions. (3) When potentially toxic or bioaccumulative chemicals are used in ponds, the water should not be discharged until the compounds have naturally decomposed to non-toxic forms. (4) Careful records should be maintained regarding use of chemicals in 
ponds as suggested by the Hazard Analysis and Critical Control Point (HACCP) method. (5) The aquaculture industry should work with governments to develop regulations for labeling the content and percentage of active ingredients in all chemicals including liming materials and fertilizers.

\section{Acknowledgements}

This study was supported by the Pond Dynamics/Aquaculture Collaborative Research Support Program (CRSP) funded by the US Agency for International Development (CRSP Accession No. 1177).

\section{References}

Avault, J.W. Jr., 1996. Fundamentals of Aquaculture. AVA Publishing, Baton Rouge, LA, pp. 1-889. Boyd, C.E., 1979. Aluminum sulfate (alum) for precipitating clay turbidity from fish ponds. Trans. Am. Fish. Soc. 108, 305-311.

Boyd, C.E., 1995a. Chemistry and efficacy of amendments used to treat water and soil quality imbalances in shrimp ponds. In: Browdy, C.L., Hopkins, J.S. (Eds.), Proceedings of the Special Session on Shrimp Farming. The World Aquaculture Society, Baton Rouge, LA, pp. 183-189.

Boyd, C.E., 1995b. Potential of sodium nitrate to improve environmental conditions in aquaculture ponds. World Aquac. 26 (2), 38-40.

Boyd, 1999. Codes of practice for responsible shrimp farming. Global Aquaculture Alliance, St. Louis, MO.

Boyd, C.E., Gross, A., 1998. Use of probiotics for improving soil and water quality in aquaculture ponds. In: Flegel, T.W. (Ed.), Advances in Shrimp Biotechnology. Proceedings to the Special Session on Shrimp Biotechnology, 5th Asian Fisheries Forum, 11-14 November 1998, Chiengmai, Thailand. The National Center for Genetic Engineering and Biotechnology, Bangkok, Thailand, pp. 101-106.

Boyd, C.E., Noor, M.H.M., 1982. Aquashade treatment of channel catfish ponds. North Am. J. Fish. Manag. 2, 193-196.

Boyd, C.E., Scarsbrook, E., 1974. Effects of agricultural limestone on phytoplankton communities of fish ponds. Arch. Hydrobiol. 74, 336-349.

Boyd, C.E., Tucker, C.S., 1998. Pond Aquaculture Water Quality Management. Kluwer, Norwell, MA.

Budavari, S., 1996. The Merck Index. An Encyclopedia of Chemicals and Drugs, 12th edn. Merck \& Co., Inc, Whitehouse Station, NJ.

Chamberlain, G., 1988. Rethinking shrimp pond management. Tex. Agric. Ext. Ser. Coast. Aquac. $2,19$.

Duncan, T.O., 1974. A Review of Literature on the Use of Potassium Permanganate $\left(\mathrm{KMnO}_{4}\right)$ in Fisheries. US Fish Wildlife Service, Report FWS-LR-74-14. pp. 61.

FAO, 1995. Code of Conduct for Responsible Fisheries. FAO, Rome, Italy, p. 41.

Federal Joint Subcommittee on Aquaculture, 1994. Guide to Drug, Vaccine, and Pesticide Use in Aquaculture. Texas Agricultural Extension Service, The Texas A\&M University System, College Station, TX.

Gross, A., Boyd, C.E., Wood, C.W., 1999. Ammonia volatilization from freshwater fish ponds, J. Environ. Qual. 28, (in press).

Hairston, J.E., Kown, S., Meetze, J., et al., 1995. Protecting Water Quality on Alabama Farms. Alabama Soil and Water Conservation Committee, Montgomery, AL.

Hunt, D., Boyd, C.E., 1981. Alkalinity losses from ammonium fertilizers used in fish ponds. Trans. Am. Fish. Soc. 109, 81-85.

Jones, U.S., 1979. Fertilizers and Soil Fertility. Reston Publishing, Reston, VA.

Lay, B.A., 1971. Applications for potassium permanganate in fish culture. Trans. Am. Fish. Soc. 100, $813-815$. 
Masuda, K., Boyd, C.E., 1993. Comparative evaluation of the solubility and algal toxicity of copper sulfate and chelated copper. Aquaculture 117, 287-302.

Mumpton, F.A., 1984. Natural zeolite. In: Pond, W.G., Mumpton, F.A. (Eds.), Zeo-agriculture. Westview Press, Boulder, CO, pp. 33-43.

Potts, A.C., Boyd, C.E., 1998. Chlorination of channel catfish ponds. J. World Aquac. Soc. 29, 432-440.

Queiroz, J.F., Boyd, C.E., 1998. Effects of a bacterial inoculum in channel catfish ponds. J. World Aquac. Soc. 29, 67-73.

Queiroz, J.F., Boyd, C.E., Gross, A., 1998. Evaluation of a bio-organic catalyst in channel catfish, Ictalurus punctatus, ponds. J. Appl. Aquac. 8, 49-61.

Scott, J.H., Bayne, D.R., Boyd, C.E., 1989. Effects of sodium ricinoleate on water quality, phytoplankton, and off-flavor in channel catfish ponds. J. Aquat. Plant Manag. 27, 26-31.

Schwartz, M.F., Boyd, C.E., 1994. Effluent quality during harvest of channel catfish from watershed ponds. Prog. Fish. Cult. 56, 25-32.

Tucker, C.S., Boyd, C.E., 1977. Relationships between potassium permanganate treatment and water quality. Trans. Am. Fish. Soc. 106, 481-488.

Tucker, C.S., Boyd, C.E., 1978. Effects of simazine treatment on channel catfish and bluegill production in ponds. Aquaculture 15, 345-352.

Tucker, C.S., Robinson, E.H., 1990. Channel Catfish Farming Handbook. Van Nostrand Reinhold, New York.

Tucker, C.S., Francis-Floyd, R., Beleau, M.H., 1989. Nitrite-induced anemia in channel catfish, Ictalurus punctatus Rafinesque. Bull. Environ. Contam. Toxicol. 43, 295-301.

Wacharonke, C., 1994. Shrimp farming: a breakthrough in controlling nitrogen metabolism and minimizing water pollution. In: Lyons, T.P., Jacques, K.A. (Eds.), Biotechnology in the Feed Industry. Nottingham University Press, Loughborough, UK, pp. 247-252.

White, G.C., 1992. The Handbook of Chlorination and Alternative Disinfectants, 3rd edn. Van Nostrand Reinhold, New York.

White, S.L., Rainbow, P.S., 1982. Regulation and accumulation of copper, zinc and cadmium by the shrimp Palaemon elegans. Mar. Ecol. Prog. Ser. 8, 95-101. 